\title{
PERAN DAN KEDUDUKAN HUKUM DOKTER KELUARGA \\ DALAM PELAYANAN KESEHATAN \\ BAGI PESERTA ASURANSI KESEHATAN \\ (PT ASKES PERSERO) DI KABUPATEN TEMANGGUNG
}

\author{
Puji Lestari, Endang Wahyati Y. dan Y. Budi Sarwo \\ pujilestari@yahoo.co.id \\ Magister Hukum Kesehatan \\ Universitas Katolik Soegijapranata Semarang
}

\begin{abstract}
ABSTRAK
Pemerintah dalam upaya peningkatan pelayanan kesehatan kepada masyarakat pada tingkat primer melalui pelayanan dokter keluarga, yang dilaksanakan oleh PT.Askes (Persero).

Metode penelitian menggunakan yuridis sosiologis dengan spesifikasi penelitian yang dipergunakan adalah deskriptif.

Hasil penelitian menunjukkan ketentuan hukum belum diatur. Peran dan kedudukan hukum dokter keluarga masih mengacu pada ketentuan perundang-undangan yang mengatur tentang dokter dan dokter gigi. Pengaturan dokter keluarga secara khusus belum ada. Kewenangan dokter keluarga sama dengan dokter dan dokter gigi. Akibat hukum dari kedudukan hukum antara dokter keluarga hubungannya dengan PT. Askes yang tidak jelas sehingga dokter keluarga tidak terlindungi secara hukum.

Pelaksanaan pelayanan dokter keluarga pada peserta askes sama dengan pasien umum, pelayanan kesehatan mengacu pada perjanjian kerjasama antara dokter keluarga dengan PT. Askes (Persero). Kesimpulannya adalah pengaturan tentang dokter keluarga belum ada sehingga tidak ada perlindungan hukum dalam melaksanakan pelayanan kesehatan bagi peserta askes. Pelaksanaan praktik dokter keluarga askes tidak sesuai dengan peraturan yang ada.
\end{abstract}

Kata kunci: Askes, Dokter Keluarga, Kedudukan Hukum 


\section{LATAR BELAKANG}

Kesehatan adalah hak asasi manusia dan sekaligus investasi untuk keberhasilan pembangunan suatu negara sebab mempunyai peranan besar dalam meningkatkan derajat hidup masyarakat. Kesinambungan dan keberhasilan pembangunan kesehatan ditentukan oleh tersedianya pedoman penyelenggaraan pembangunan kesehatan baik berupa dokumen perencanaan maupun metode dan cara penyelenggaraannya.

Upaya pelayanan kesehatan perorangan primer adalah pelayanan kesehatan dimana terjadi kontak pertama secara perorangan sebagai proses awal pelayanan kesehatan. Pelayanan kesehatan perorangan primer diselenggarakan oleh tenaga kesehatan yang dibutuhkan dan mempunyai kompetensi seperti yang ditetapkan sesuai ketentuan berlaku serta dapat dilaksanakan di rumah, tempat kerja, maupun fasilitas kesehatan perorangan primer baik puskesmas dan jaringannya, serta fasilitas kesehatan lainnya milik pemerintah, masyarakat maupun swasta. Penyelenggaraan pelayanan kesehatan masyarakat primer menjadi tanggung jawab Dinas Kesehatan Kabupaten yang pelaksanan operasionalnya dapat didelegasikan kepada Puskesmas.

Jaminan sosial merupakan bentuk perlindungan sosial yang diselenggarakan negara guna menjamin warganya untuk memenuhi kebutuhan dasar hidup yang layak. Tertuang dalam Undang-Undang Nomor 40 Tahun 2004 tentang Sistem Jaminan Sosial Nasional (selanjutnya disebut Undang-Undang SJSN).

Pembiayaan pelayanan kesehatan masyarakat primer ditanggung oleh pemerintah bersama masyarakat, termasuk swasta, yang berhubungan dengan prioritas pembangunan kesehatan melalui kegiatan perbaikan lingkungan, peningkatan kesehatan, pencegahan penyakit dan kematian serta paliatif. Salah satunya melalui PT Askes yang melakukan pelayanan kesehatan kepada peserta askes melalui dokter keluarga. Sejak tahun 2003 PT Askes telah menerapkan Dokter Keluarga sebagai mitra dalam melaksanakan kegiatan pemberi pelayanan kesehatan (PPK) dengan pelayanan rawat jalan tingkat pertama terhadap peserta askes. Pengembangan konsep dokter keluarga oleh PT. Askes bertujuan untuk meningkatkan aspek mutu pelayanan dan pengendalian biaya pelayanan kesehatan.

Pelayanan dokter keluarga merupakan upaya penyelenggaraan pelayanan kesehatan tingkat primer untuk memenuhi ketersediaan, ketercapaian, keterjangkauan dan kesinambungan mutu pelayanan kesehatan bagi masyarakat sampai paripurna. Dokter keluarga adalah dokter umum yang dalam prakteknya menggunakan pendekatan kedokteran keluarga atau dokter penyelenggara primer yang berprofesi sebagai dokter praktek umum. Di Indonesia praktek dokter keluarga belum berfungsi sebagai penyelengara pelayanan primer.

Dokter keluarga diperlukan dalam pelayanan kesehatan di Indonesia karena banyak penyakit yang bisa dilakukan pencegahan, oleh karena itu diperlukan dokter keluarga di masyarakat. Dokter keluarga harus mengenal setiap anggota keluarga yang menjadi langganannya, agar setiap anggota keluarga terjamin dan aman dalam berobat.

Pedoman tentang pelaksanaan dokter keluarga sebagai tenaga kesehatan dalam pelayanan kesehatan masyarakat strata pertama tidak ada. Sekalipun organisasi ini sejak tahun 1988 telah menjadi anggota IDI, tapi pelayanan dokter keluarga di Indonesia belum secara resmi mendapat pengakuan dari profesi kedokteran ataupun dari pemerintah.

Keberadaan dokter keluarga di Kabupaten Temanggung sudah ada dan sudah melaksanakan kegiatan pelayanan kesehatan terhadap peserta askes akan tetapi peraturan belum ada sehingga kedudukan hukum dokter keluarga tidak jelas. Oleh karena itulah menarik untuk diteliti mengenai peran dan kedudukan hukum dokter keluarga dalam pelayanan kesehatan bagi peserta asuransi kesehatan (PT ASKES PERSERO) di Kabupaten Temanggung. 


\section{PERUMUSAN MASALAH}

Dengan merunut uraian mengenai latar belakang masalah sebagaimana tersebut diatas, penelitian ini merumuskan beberapa permasalahan sebagai berikut:

1. Bagaimana ketentuan peran dan kedudukan hukum dokter keluarga askes ?

2. Bagaimana pelaksanaan pelayanan kesehatan oleh dokter keluarga terhadap peserta askes di Kabupaten Temanggung?

3. Faktor- faktor yang mempengaruhi pelaksanaan pelayanan kesehatan oleh dokter keluarga terhadap peserta askes di Kabupaten Temanggung?

\section{METODE PENELITIAN}

Metode penelitian yang digunakan adalah yuridis sosiologis. Dengan spesifikasi penelitian yang dipergunakan adalah deskriptif. Fokus penelitian terletak pada peran dan kedudukan hukum dokter keluarga dalam pelayanan kesehatan bagi peserta askes di Kabupaten Temanggung.

\section{PEMBAHASAN PENELITIAN}

\section{Ketentuan Peran dan Kedudukan Hukum Dokter Keluarga}

\section{a. Dasar Hukum Tentang Dokter Keluarga}

1) Undang-Undang Nomor 36 Tahun 2009 tentang Kesehatan

Dokter keluarga adalah tenaga kesehatan, bahwa yang dimaksud dengan tenaga kesehatan menurut Undang-Undang Kesehatan Pasal 1 butir 6 "tenaga kesehatan adalah setiap orang yang mengabdikan diri dalam bidang kesehatan serta memiliki pengetahuan dan/atau ketrampilan melalui pendidikan dibidang kesehatan yang untuk jenis tertentu memerlukan kewenangan untuk melakukan upaya kesehatan".

Ketentuan undang-undang mensyaratkan bahwa diperlukan kewenangan untuk melakukan upaya kesehatan bagi tenaga kesehatan, demikian juga dokter keluarga. Kewenangan dokter keluarga berkaitan dengan persyaratan dokter umum yaitu mempunyai STR, SIP yang dikeluarkan oleh Konsil Kedokteran Indonesia. Dan kewenangan secara yuridis harus memiliki surat seperti tersebut. Dari hasil penelitian ada ketidak pengertian dari responden bahwa syarat menjadi dokter keluarga ada yang mengatakan tidak memerlukan persyaratan. Seharusnya setiap dokter yang melaksanakan praktik kedokteran memiliki persyaratan yang tertuang dalam perundang-undangan yang berlaku.

2) Undang-Undang Nomor 29 Tahun 2004 tentang Praktek Kedokteran

Dalam Undang-Undang Nomor 29 Tahun 2004 tentang Praktek kedokteran Pasal 1 butir 2 yang dimaksud dokter adalah "dokter dan dokter gigi adalah dokter, dokter spesialis, dokter gigi, dan dokter gigi spesialis lulusan pendidikan kedokteran atau kedokteran gigi baik didalam maupun diluar negeri yang diakui oleh Pemerintah Republik Indonesia sesuai dengan peraturan perundang-undangan".

Dokter keluarga adalah dokter umum yang di dalam negeri yang diakui oleh Pemerintah Republik Indonesia sesuai dengan peraturan perundang-undangan. Namun secara khusus pengertian dokter keluarga tidak ditemukan di dalam ketentuan undang-undang ini sehingga saat dokter keluarga adalah dokter umum karena pelayanannya adalah pelayanan kesehatan umum dan medik dasar maka dokter keluarga adalah sama dengan dokter umum.

\section{3) Peraturan Pemerintah Nomor 32 tahun 1996 tentang Tenaga Kesehatan}


Dalam Peraturan Pemerintah Nomor 32 tahun 1996 tentang tenaga kesehatan Pasal 1 butir 1 yang dimaksud dengan tenaga kesehatan adalah "Tenaga Kesehatan adalah setiap orang yang mengabdikan diri dalam bidang kesehatan serta memiliki pengetahuan dan/atau keterampilan melalui pendidikan di bidang kesehatan yang untuk jenis tertentu memerlukan kewenangan untuk melakukan upaya kesehatan". Demikian juga dengan dokter keluarga sebagai tenaga kesehatan, memerlukan kewenangan tersebut.

\section{4) Permenkes Nomor 2052 tahun 2011 tentang Izin Praktik dan Pelaksanaan Praktik Kedokteran}

Dalam Permenkes Nomor 2052 tahun 2011 tentang Izin Praktik dan Pelaksanaan Praktik Kedokteran Pasal 1 butir 1 dikatakan "Praktik kedokteran adalah rangkaian kegiatan yang dilakukan oleh dokter dan dokter gigi terhadap pasien dalam melaksanakan upaya kesehatan".

Pasal 1 butir 2 berbunyi "dokter dan dokter gigi adalah lulusan pendidikan kedokteran atau kedokteran gigi baik di dalam maupun luar negeri yang diakui oleh Pemerintah Republik Indonesia sesuai dengan peraturan perundang-undangan".

Ketentuan perundang-undangan di atas mengatakan bahwa praktik kedokteran adalah rangkaian kegiatan yang dilakukan oleh dokter dan dokter gigi terhadap pasien dalam melaksanakan upaya kesehatan, jadi dokter keluarga dalam melakukan upaya kesehatan juga termasuk didalam praktik kedokteran. Sehingga upaya kesehatan oleh dokter keluargapun membutuhkan suatu kewenangan.

Jika dokter keluarga merupakan ruang lingkup kewenangannya khusus maka keberadaan dokter keluarga secara yuridis belum mempunyai dasar hukum. Kewenangan dokter keluarga secara profesional sama dengan dokter umum. Kewenangan dokter keluarga secara khusus hanya ada pada ruang lingkup pembiayaan pasien peserta asuransi kesehatan yang ditentukan oleh PT. Askes.

Pada Pasal 1 butir 4 berbunyi " Surat Izin Praktik selanjutnya disebut SIP adalah bukti tertulis yang diberikan dinas kesehatan kabupaten /kota kepada dokter dan dokter gigi yang akan menjalankan praktik kedokteran setelah memenuhi persyaratan". Kemudian dalam Pasal 2 butir 1 dikatakan "Setiap Dokter dan Dokter gigi yang menjalankan praktik kedokteran wajib memiliki SIP".

Dari hasil penelitian menunjukkan bahwa semua dokter keluarga memiliki SIP oleh karena itu dapat disimpulkan bahwa semua dokter keluarga memenuhi ketentuan Pasal 1 butir 4 Permenkes Nomor 2052 tahun 2011 tentang Izin Praktik dan Pelaksanaan Praktik Kedokteran.

Dalam Pasal 1 butir 11 berbunyi "Standar Prosedur Operasional adalah suatu perangkat instruksi/langkah-langkah yang dibakukan untuk menyelesaikan suatu proses kerja rutin tertentu, dimana standar prosedur operasional memberikan langkah yang benar dan terbaik berdasarkan konsensus bersama untuk melaksanakan berbagai kegiatan dan fungsi pelayanan yang dibuat oleh sarana pelayanan kesehatan berdasarkan standar profesi". Peraturan perundang-undangan menyebutkan bahwa standar prosedur operasional memberikan langkah yang benar dan terbaik berdasarkan konsensus bersama untuk melaksanakan berbagai kegiatan dan fungsi pelayanan yang dibuat oleh sarana pelayanan kesehatan berdasarkan standar profesi, tetapi dalam pelaksanaan pelayanan kesehatan yang dilakukan oleh dokter keluarga tidak ada Standar Prosedur Operasional untuk dokter keluarga sehingga pelaksanaan pelayanan kesehatan yang diberikan dokter keluarga juga tidak jelas. 


\section{5) Permenkes Nomor 416 tahun 2011 tentang Tarif Pelayanan Kesehatan bagi Peserta PT Askes (Persero)}

Disebutkan dalam Permenkes Nomor 416 tahun 2011 tentang Tarif Pelayanan Kesehatan bagi Peserta PT Askes (Persero) Pasal 1 butir 7 bahwa dokter keluarga adalah "dokter praktek umum yang menyelenggarakan pelayanan primer yang komprehensif, kontinu, mengutamakan pencegahan, koordinatif, mempertimbangkan keluarga, komunitas dan lingkungannya dilandasi ketrampilan dan keilmuan yang mapan yang telah dilakukan kredensialing oleh PT Askes (Persero)".

Berdasarkan hasil penelitian proses untuk menjadi dokter keluarga di Kabupaten Temanggung adalah dokter praktek umum yang dalam penyelenggaraan pelayanan kesehatan terhadap peserta askes mengutamakan pelayanan kuratif. Pelaksanaan, ketrampilan dan keilmuan sama dengan dokter praktek umum. Dokter keluarga dalam melaksanakan upaya pelayanan atas penunjukan dan penawaran dari PT Askes, kredensialing tidak dilaksanakan oleh PT Askes. Dokter keluarga askes tidak mengetahui tentang kredensialing yang dilakukan oleh PT Askes, dokter keluarga dapat segera melaksanakan praktek pelayanan dokter keluarga segera setelah ada perjanjian dengan PT Askes.

Perekrutan dan penunjukan dokter keluarga dilakukan karena beberapa dokter keluarga merasa kesulitan dalam mendapatkan pasien, sehingga dari PT. Askes berdasarkan data dari dinas kesehatan melakukan penunjukan dan penawaran dengan syarat berpraktik menetap di satu wilayah minimal selama 5 tahun.

\section{b. Bentuk Pengaturan Dokter Keluarga}

Bentuk pengaturan dokter keluarga secara khusus tidak ada. Secara tidak langsung dokter keluarga diatur dalam Permenkes Nomor 416 tahun 2011 tentang Tarif Pelayanan Kesehatan bagi Peserta PT Askes (Persero), sedangkan yang secara langsung diatur dalam bentuk perjanjian kerjasama antara dokter keluarga dengan PT Askes (Persero).

Berdasarkan hasil penelitian bentuk pengaturan dokter keluarga hanya terdapat dalam Permenkes Nomor 416 tahun 2011 tentang Tarif Pelayanan Kesehatan bagi Peserta PT Askes (Persero) dan dalam perjanjian kerjasama antara PT Askes persero dengan dokter keluarga.

\section{c. Tujuan Pengaturan Dokter Keluarga}

Tujuan pengaturan keberadaan dokter keluarga dilihat dari kewenangan dokter keluarga, hal ini untuk menjamin perlindungan hukum bagi dokter keluarga dan perlindungan hukum bagi masyarakat khususnya peserta askes sebagai pasiennya. Kewenangan dokter keluarga ini terkait dengan persyaratan sebagai dokter keluarga, tidak adanya persyaratan yang jelas menjadikan kewenangan dokter keluargapun menjadi tidak jelas.

Bentuk pengaturan dokter keluarga hanya terdapat dalam perjanjian kerjasama, antara dokter keluarga dengan PT. Askes. Sedangkan tujuan yang secara khusus mengatur tentang dokter keluarga juga hanya dalam perjanjian kerjasama antara dokter keluarga dengan PT. Askes. Tujuan pengaturan lebih mengatur hubungan hukum antara dokter keluarga dan PT. Askes. Pengaturan tentang pasien yang menyangkut hak dan kewajiban pasien sebagai penerima tindakan atas pelayanan kesehatan oleh dokter keluarga tidak tertuang dalam isi perjanjian kerjasama antara dokter keluarga dengan PT. Askes.

Berdasarkan dari hasil penelitian tujuan pengaturan tersebut diatur dalam bentuk Perjanjian kerjasama yang dilaksanakan antara dokter keluarga dengan PT Askes, perjanjian kerjasama memuat tentang kewajiban dokter keluarga untuk memberikan pelayanan berupa upaya kesehatan kepada peserta askes. sedangkan pembiayaan 
dilakukan oleh PT. Askes berupa klaim tiap bulan sesuai kapitasi. Seharusnya perjanjian memuat hal-hal sesuai asas hukum yaitu: asas kepastian hukum, manfaat dan perlindungan hukum bagi dokter keluarga dan PT. Askes.

\section{d. Kedudukan Hukum Dokter Keluarga}

Berdasarkan penelitian konsep dokter keluarga adalah pelaksanan pelayanan kesehatan untuk dan atas nama PT. Askes, dalam bentuk pelayanan kesehatan umum bagi peserta askes. Jika dilihat dari kedudukan hukum, maka kedudukan hukumnya ada tiga pihak, yaitu yang pertama antara PT. Askes dengan dokter keluarga kemudian yang kedua antara dokter keluarga dengan peserta askes, dan yang ketiga hubungan antara PT. Askes dengan peserta.

Dalam konteks penelitian ini yang menjadi obyek kajian adalah hubungan hukum antara dokter keluarga dengan PT. Askes yang merupakan bagian dari ruang lingkup hukum perdata, dalam hubungannya dengan PT. Askes adalah sebagai subyek hukum pelaksana pekerjaan dan PT. Askes sebagai pemberi pekerjaan. Sedangkan hubungan hukum antara dokter keluarga dengan peserta askes merupakan hubungan terapeutik, dimana hubungan antara dokter keluarga dengan pasien yaitu peserta askes menerima layanan kesehatan dari dokter keluarga, sebagai hubungan hukum perdata.

Hubungan hukum yang selanjutnya antara PT. Askes dengan peserta askes, dimana PT. Askes bertindak sebagai pemberi imbalan terhadap jasa yang diberikan dokter keluarga terhadap peserta askes, atas nama pemerintah, dalam hal ini hubungan hukum yang terjadi adalah hubungan administrasi.

Dalam menjalankan pelayanan kesehatan ini dokter keluarga maupun peserta askes yang menjadi tanggungan dokter keluarga harus mendapatkan perlindungan. Berbicara mengenai perlindungan hukum berarti membahas tentang hak dan kewajiban. Perlindungan hukum bagi dokter keluarga berarti berbicara tentang hak dokter keluarga setelah melaksanakan kewajibannya dalam pelayanannya sebagai tenaga kesehatan di sarana pelayanan kesehatan bagi peserta askes. Perlindungan hukum diberikan bagi tenaga kesehatan (dokter keluarga) sebagai subyek hukum yang melakukan tugasnya sesuai dengan standar profesinya.

Karena hak dokter keluarga yang dimaksud dalam perjanjian kerjasama hanya hak menerima pembayaran atas biaya kapitasi setiap bulan sesuai ketentuan yang berlaku di PT. Askes. Sedangkan kewajiban dokter keluarga dalam perjanjian kerjasama dengan PT. Askes memberi pelayanan kepada peserta,memberikan informasi dan laporan pada PT. Askes, menyediakan pengganti dokter bila berhalangan, menyediakan obat, mengendalikan angka rujukan, melayani peserta dengan baik, membantu terlaksananya program PT. Askes terkait dokter keluarga, membuat papan nama dokter keluarga, membantu program pelayanan penyakit kronis (prolanis). Dengan demikian dokter keluarga tidak terlindungi karena tidak ada pengaturan perlindungan hak dokter keluarga. Di dalam perjanjian kerjasama tidak membahas perlindungan tersebut, seharusnya isi perjanjian kerjasama sesuai dengan Undang-undang Praktik kedokteran dan Permenkes 416 tahun 2011, yang melindungi hak dokter.

\section{Pelaksanaan Pelayanan Kesehatan oleh Dokter Keluarga Terhadap Peserta Asuransi Kesehatan di Kabupaten Temanggung}

Dalam pelaksanaan pelayanan kesehatan dimana kedudukan dokter keluarga sebagai pelaksana pelayanan kesehatan PT. Askes maka kedudukan hukum dirumuskan dalam perjanjian kerjasama antara dokter keluarga dengan PT. Askes. Pelaksanaan pelayanan kesehatan yang diberikan kepada peserta askes sesuai dengan pelayanan kesehatan primer 
tingkat pertama, akan tetapi dalam hal pelayanan yang tidak dapat dilaksanakan oleh dokter keluarga dan harus dirujuk, dan ada pembatasan dari PT. Askes.

\section{a. Prosedur Pelayanan Kesehatan oleh Dokter Keluarga Terhadap Peserta Asuransi Kesehatan di Kabupaten Temanggung}

Pertama dokter keluarga memiliki hubungan hukum dengan PT. Askes dalam kerjasama yang tertuang dalam Perjanjian Kerjasama, yang antara lain membahas mengenai hak dan kewajiban dokter keluarga dalam memberikan pelayanan kepada peserta askes dan hak peserta asuransi kesehatan, karena kewajiban peserta tidak dibahas dalam perjanjian kerjasama antara dokter keluarga dengan PT. Askes.

Kedua pelayanan kepada peserta askes yang pertama dokter keluarga harus memiliki sarana praktik, mempunyai kerjasama dengan PT. Askes yang tertuang dalam bentuk Perjanjian Kerjasama, mempunyai Surat ljin praktik (SIP), Surat Tanda Registrasi (STR), serta dilakukan kredensialing untuk menilai kelayakan dari dokter yang akan menjadi dokter keluarga.

Peserta asuransi kesehatan dalam mendapatkan pelayanan dokter keluarga harus terdaftar sebagai peserta asuransi kesehatan, mendaftarkan ke PT. Askes dan mengisi formulir atau mendaftar langsung ke dokter keluarga yang menjadi rujukan dari PT. Askes, dengan membawa kartu askes.

Dari hasil penelitian prosedur pelaksanaan pelayanan kesehatan oleh dokter keluarga tidak ada persyaratan dan pemahaman yang jelas antara dokter keluarga dengan PT. Askes hal ini dapat disebutkan karena dalam keterangannya beberapa responden mengatakan tidak ada persyaratan tertentu untuk menjadi dokter keluarga dan untuk melayani peserta askes, peserta askes sebagian memberikan keterangan tidak memilih dokter keluarga tetapi sudah masuk dalam daftar pasien dokter keluarga, yang lain sesuai dengan ketentuan yaitu mendaftar langsung ke PT. Askes atau ke sarana kesehatan dengan mengisi formulir serta membawa kartu askes. Hasil penelitian menunjukkan adanya ketidak sesuaian antara prosedur dalam perjanjian kerjasama yang telah ditentukan dengan praktik yang dilaksanakan.

\section{b. Ruang lingkup Pelayanan Kesehatan oleh Dokter Keluarga Terhadap Peserta Asuransi Kesehatan di Kabupaten Temanggung}

Berdasarkan Permenkes Nomor 416 tahun 2011 tentang Tarif Pelayanan Kesehatan bagi Peserta PT. Askes (Persero) bahwa dokter keluarga menyelenggarakan pelayanan primer yang komprehensif, kontinu, mengutamakan pencegahan, koordinatif, mempertimbangkan keluarga, komunitas dan lingkungannya dilandasi ketrampilan dan keilmuan yang mapan yang telah dilakukan kredensialing oleh PT. Askes (Persero). Serta berdasarkan perjanjian kerjasama antara dokter keluarga dengan PT. Askes.

Dari hasil penelitian ruang lingkup pelayanan dokter keluarga yang dilaksanakan di Kabupaten Temanggung ada pembatasan pelayanan kesehatan yang dilaksanakan oleh dokter keluarga yaitu sebagai berikut: pemeriksaan umum, konsultasi, pengobatan (Kuratif) dan rujukan, sedangkan yang direkomendasikan oleh PT. Askes adalah tindakan kuratif saja, untuk tindakan rujukan sangat dibatasi yaitu $10 \%$ dari jumlah peserta yang periksa. Sementara dalam perjanjian kerjasama ruang lingkup pelayanan kesehatan terhadap peserta askes lebih luas. Hal ini tidak sesuai dengan ketentuan Permenkes Nomor 416 tahun 2011 tentang Tarif Pelayanan Kesehatan bagi Peserta PT. Askes (Persero). 
Sejauh ini pelaksanaan ruang lingkup pelayanan kesehatan oleh dokter keluarga di Kabupaten Temanggung membatasi hak peserta askes karena ruang lingkup lebih sempit dari yang seharusnya diterima oleh peserta asuransi kesehatan yang ditetapkan dalam perjanjian kerjasama maupun peraturan perundang-undangan yang ada. Karena peserta asuransi kesehatan tidak mengetahui pelayanan kesehatan apa saja yang bisa diterima dalam pelayanan dokter keluarga.

\section{c. Akibat Hukum Pelaksanaan Pelayanan Kesehatan oleh Dokter Keluarga Kepada Peserta Asuransi Kesehatan di Kabupaten Temanggung}

Akibat hukum adalah akibat yang ditimbulkan oleh hukum atas suatu tindakan subyek hukum. Akibat hukum ini menyangkut hak dan kewajiban subyek hukum. Berdasarkan hasil penelitian maka akibat hukumnya dapat diuraikan sebagai berikut:

1) Akibat hukum antara dokter keluarga dengan PT. Askes.

Akibat hukum ini menyangkut hak dan kewajiban antara dokter keluarga dengan PT. Askes, hak dan kewajiban antara dokter keluarga adalah melaksanakan apa yang menjadi tanggungannya seperti yang tertuang dalam perjanjian kerjasama dalam memberikan upaya pelayanan kesehatan kepada peserta askes atas nama PT. Askes.

Dalam perjanjian kerjasama antara PT. Askes persero dengan dokter keluarga, hak dokter keluarga hanya berhak menerima pembayaran atas biaya kapitasi setiap bulannya sesuai ketentuan yang berlaku. Ketentuan yang berlaku ini mengatur tentang besaran nilai yang dibayarkan PT. Askes kepada dokter keluarga, dokter keluarga tidak boleh menarik iur dari peserta askes, serta pemotongan untuk biaya pengawasan dan pembinaan oleh dinas kesehatan.

Sedangkan kewajiban dari dokter keluarga atas perjanjian kerjasama dengan PT. Askes adalah menyangkut beberapa hal sebagai berikut: memberi pelayanan kepada peserta terdaftar, memberi informasi dan laporan pada pihak pertama yaitu PT. Askes (Persero), menyediakan dokter pengganti bila berhalangan, menyediakan obat akut atau bekerjasama dengan apotik yang ditunjuk, mengendalikan angka rujukan tidak lebih dari 10\%, melayani peserta askes dengan baik untuk meningkatkan kepuasan peserta, membantu terlaksananya program-program PT. Askes yang terkait dengan dokter keluarga, membuat papan nama dokter keluarga sesuai standart, membantu penyelenggaraan program Prolanis dan rujuk balik.

Dengan demikian antara hak dan kewajiban dokter keluarga tidak sebanding karena haknya hanya satu sedangkan kewajibannya ada sembilan. Hak dokter keluarga untuk mendapatkan perlindungan hukum, perlindungan terhadap bahaya penularan penyakit dan akibat dari kejadian tidak diinginkan tidak diatur dalam perjanjian kerjasama ini.

2) Akibat hukum antara dokter keluarga dengan peserta askes

Akibat hukum menyangkut hak dan kewajiban antara dokter keluarga dengan peserta askes dalam hubungan terapeutik. Dimana dokter keluarga berkewajiban memberikan pelayanan kesehatan kepada peserta askes sesuai isi perjanjian kerjasama antara dokter keluarga dengan PT. Askes (Persero). Sedangkan hak dokter keluarga dalam menerima imbalan dipenuhi oleh PT. Askes. Hak paserta menerima pelayanan kesehatan yang diberikan oleh dokter keluarga, sedangkan kewajibannya adalah kewajiban administrasi dimana peserta askes jika akan mendapatkan pelayanan kesehatan oleh dokter keluarga harus membawa kartu askes.

Dokter keluarga tidak terlindungi secara hukum dalam melaksanakan tindakan terapeutik terhadap peserta askes, karena tidak ada dalam peraturan perundangan 
maupun dalam perjanjian kerjasama. Perjanjian kerjasama antara dokter keluarga dengan PT. Askes tidak memenuhi asas hukum yaitu: asas kepastian hukum, asas manfaat dan asas perlindungan hukum bagi dokter keluarga.

3) Akibat hukum antara PT. Askes dengan peserta asuransi kesehatan

Akibat hukum menyangkut hak dan kewajiban antara PT. Askes (Persero) dengan peserta asuransi kesehatan. Hak PT. Askes menerima iuran dari peserta asuransi kesehatan sedangkan kewajiban PT. Askes adalah membayarkan yang menjadi kewajiban dari peserta askes kepada dokter keluarga dalam memberikan pelayanan kesehatan kepada peserta askes. Peserta askes haknya menerima jasa pelayanan kesehatan yang diberikan oleh dokter keluarga, sedangkan kewajibannya membayar iuran kepada PT. Askes (Persero).

Dengan demikian hak dan kewajiban dokter keluarga dalam hubungannya dengan PT. Askes tidak sebanding dan tidak terlindungi secara hukum. Hak dan kewajiban antara dokter keluarga dengan peserta askes tidak diatur dalam perundangundangan, sedangkan hak dan kewajiban antara PT. Askes dengan peserta askes diatur dalam Pedoman bagi Peserta Askes Sosial (PT. Persero. Asuransi Kesehatan Indonesia. 2002).

\section{Faktor-faktor yang Mempengaruhi Pelaksanaan Pelayanan Kesehatan oleh Dokter Keluarga Terhadap Peserta Asuransi Kesehatan di Kabupaten Temanggung}

\section{a. Faktor Yuridis}

Faktor yuridis yang mempengaruhi belum ada ketentuan mengatur tentang dokter keluarga. Kewenangan dokter keluarga hanya termuat dalam Permenkes Nomor 416 tahun 2011 tentang Tarif Pelayanan Kesehatan bagi Peserta PT. Askes (Persero) dan perjanjian kerjasama antara dokter keluarga dengan PT Askes.

Sehingga secara yuridis dokter keluarga sebagai pelaksana pelayanan kesehatan maupun peserta askes sebagai penerima jasa layanan kesehatan tidak terlindungi.

\section{b. Faktor Administratif}

Faktor administratif yaitu dokter keluarga tidak terdokumentasi dengan baik pada Dinas Kesehatan, pengawasan tidak berjalan denganbaik, dokter keluarga tidak terlaporkan.

Hasil penelitian di dapatkan sebagian peserta asuransi kesehatan tidak mengetahui adanya dokter keluarga tetapi sudah terdaftar dalam dokter keluarga. Proses perpindahan dari sarana kesehatan selain dokter keluarga atau antar dokter keluarga memerlukan waktu 3 bulan. Adanya batasan pelayanan, batasan tindakan, batasan obatobatan, batasan rujukan.

\section{c. Faktor demografi}

Faktor demografi yang mempengaruhi adalah domisili dari peserta askes sebagian besar di wilayah perkotaan dan persebaran yang tidak merata, hanya dokter keluarga yang berpraktik di perkotaan dengan peserta menumpuk banyak dan di wilayah kecamatan peserta askes yang menggunakan jasa dokter keluarga sedikit.

\section{d. Faktor sosial}

Faktor sosial yang mempengaruhi adalah, tingkat pengetahuan dari peserta askes yang berbeda-beda berpengaruh dalam pemilihan sarana pelayanan kesehatan. Peserta dengan golongan II,III dan IV memilih dokter keluarga, sedangkan peserta dengan golongan I dan sebagian golongan II memilih pelayanan kesehatan puskesmas. 
Pengetahuan peserta asuransi kesehatan tentang dokter keluarga masih kurang karena sosialisasi dari PT. Askes tentang dokter keluarga yang minim.

Dari beberapa faktor yang mempengaruhi pelaksanaan pelayanan kesehatan oleh dokter keluarga terhadap peserta asuransi kesehatan di atas, bahwa ada faktor yang menghambat maupun mendukung dalam pelaksanaan pelayanan kesehatan oleh dokter keluarga.

Faktor-faktor yang mendukung pelaksanaan pelayanan dokter keluarga antara lain: proses pelayanan dokter keluarga yang mudah, peserta asuransi kesehatan bisa periksa pagi atau sore hari, peserta dapat periksa beberapa kali dalam sebulan tanpa adanya tambahan biaya, peserta bisa konsultasi lebih mendalam dengan dokter keluarganya, bisa memperoleh obat langsung.

Sedangkan faktor-faktor yang menghambat antara lain tingkat pengetahuan peserta tentang dokter keluarga kurang, informasi tentang dokter keluarga kurang, peserta mengetahui dokter keluarga dari teman maupun media, sosialisasi dari PT. Askes kurang, sebagian dokter keluarga kesulitan dalam perekrutan peserta askes, tempat tinggal peserta yang jauh dari jangkauan dokter keluarga, peserta tidak mengerti hak dari layanan dokter keluarga, pemahaman dokter keluarga tentang konsep dokter keluarga kurang.

\section{KESIMPULAN}

Berdasarkan uraian hasil penelitian dan pembahasan mengenai ketentuan peran dan kedudukan hukum dokter keluarga, pelaksanaan pelayanan kesehatan oleh dokter keluarga terhadap peserta askes, serta faktor-faktor yang mempengaruhi pelaksanaan pelayanan kesehatan oleh dokter keluarga terhadap peserta askes di Kabupaten Temanggung, maka dapat disimpulkan sebagai berikut:

1. Ketentuan Peran dan Kedudukan Hukum Dokter Keluarga

Ketentuan peran dan kedudukan hukum dokter keluarga dapat disimpulkan sebagai berikut:

a. Dasar Hukum tentang Dokter keluarga

Dasar hukum mengenai peran dan kedudukan dokter keluarga berdasarkan pada ketentuan perundang-undangan adalah sebagai berikut:

1) Undang-Undang Nomor 36 Tahun 2009 Tentang Kesehatan Pasal 1

2) Undang-Undang Nomor 29 Tahun 2004 tentang Praktik Kedokteran Pasal 1

3) Peraturan Pemerintah Nomor 32 tahun 1996 tentang Tenaga kesehatan Pasal 1.

4) Permenkes Nomor 2052 tahun 2011 tentang Izin Praktik dan Pelaksanaan Praktik Kedokteran Pasal 1 butir (2), butir (4), butir (11).

5) Permenkes Nomor 416 tahun 2011 tentang Tarif Pelayanan Kesehatan bagi Peserta PT Askes (Persero) Pasal 1 butir (7).

Dari dasar hukum tersebut ketentuannya hanya bersifat umum yang mengatur tentang dokter dan dokter gigi, bukan mengatur tentang pelayanan khusus mengenai dokter keluarga dalam arti pelayanan terhadap peserta askes. Pengaturan mengenai sifat pelayanan yang khusus kaitannya dengan kewenangan dokter keluarga. Ketentuan berdasarkan pada sifat pelayanannya dasar hukumnya tidak jelas.

b. Bentuk Pengaturan Dokter Keluarga 
Bentuk pengaturan tentang dokter keluarga dalam ketentuan hukum sebagai berikut:

1) Permenkes Nomor 416 tahun 2011 tentang Tarif Pelayanan Kesehatan bagi Peserta PT Askes (Persero) Pasal 1 butir (7).

2) Perjanjian kerjasama antara PT Askes (Persero) dengan dokter keluarga.

Berdasarkan pada ketentuan tersebut, maka bentuk pengaturan dokter keluarga sudah jelas, sedangkan dalam perjanjian kerjasama antara dokter keluarga dengan PT Askes (Persero), hanya mengatur tentang hubungan kerjasama antara dokter keluarga dengan PT Askes (Persero), pengaturan mengenai bentuk pelayanan kesehatan terhadap peserta askes dan hak serta kewajiban kedua belah pihak. Pengaturan mengenai hak untuk mendapatkan perlindungan tidak ada, pengaturan yang lebih mendasar oleh dokter keluarga tidak ada.

c. Tujuan Pengaturan Dokter Keluarga

Adapun tujuan dari pengaturan dokter keluarga seperti tercantum dalam Undang-Undang Nomor 29 tahun 2004 Tentang Praktik Kedokteran Pasal 45 ayat (3), 50, 51, 52, 53,71, 72.

Berdasarkan dari ketentuan tersebut tujuan pengaturan dokter keluarga tidak ada. Tujuan pengaturan yang ada adalah tentang dokter dan dokter gigi, apabila dokter keluarga sama dengan dokter dan dokter gigi maka tujuan pengaturan sudah diatur dalam peraturan perundang-undangan tersebut. Tujuan pengaturan terdapat di dalam perjanjian kerjasama antara dokter keluarga dengan PT. Askes.

\section{d. Kedudukan Hukum Dokter Keluarga}

Kedudukan hukum terkait dengan hubungan hukum antara dokter keluarga dengan PT Askes (Persero), maka kedudukan dokter keluarga secara hukum tidak terlindungi karena tidak ada ketentuan yang menjelaskan dalam hubungan kerjasama antara keduanya.

Kedudukan hukum dalam hubungan antara dokter keluarga dengan peserta askes sebagai pasien sudah sesuai dengan ketentuan perundang-undangan. Sedangkan kedudukan hukum yang selanjutnya dalam hubungan hukum antara PT askes dengan peserta asuransi kesehatan yang sudah diatur dalam Pedoman bagi Peserta Askes Sosial (PT. Askes Persero) Asuransi Kesehatan Indonesia.

2. Pelaksanaan Pelayanan Kesehatan oleh Dokter Keluarga Terhadap Peserta Asuransi Kesehatan di Kabupaten Temanggung

a. Prosedur pelayanan kesehatan oleh dokter keluarga terhadap peserta askes di Kabupaten Temanggung

Prosedur pelayanan kesehatan oleh dokter keluarga terhadap peserta asuransi kesehatan, didasarkan pada persyaratan dokter keluarga sudah sesuai dengan ketentuan yang berlaku. Prosedur pelayanan lebih pada proses administratif. Akan tetapi dalam pelayanan terhadap peserta askes tidak sesuai antara ketentuan dengan pelaksanaan yang terjadi.

b. Ruang Lingkup Pelayanan Kesehatan oleh Dokter Keluarga Terhadap Peserta Asuransi Kesehatan di Kabupaten Temanggung

Ruang lingkup pelayanan kesehatan oleh dokter keluarga tertuang dalam Permenkes Nomor 416 tahun 2011 tentang Tarif Pelayanan Kesehatan bagi Peserta PT Askes (Persero). Dalam pelayanan kesehatan terhadap peserta askes ruang lingkup yang dilaksanakan tidak sesuai dengan Permenkes, karena peserta tidak mengetahui pelayanan kesehatan yang dapat diterima di sarana dokter keluarga.

c. Akibat Hukum Pelaksanaan Pelayanan Kesehatan oleh Dokter Keluarga Kepada Peserta Asuransi Kesehatan di Kabupaten Temanggung 
Dari hasil penelitian dan pembahasan dalam perjanjian kerjasama antara dokter keluarga dengan PT. Askes yang menyangkut hak dan kewajiban dari masing-masing pihak dapat disimpulkan bahwa hak dari dokter keluarga hanya menerima pembayaran sesuai ketentuan yang berlaku dan dokter keluarga sangat tergantung dengan ketentuan dari PT. Askes dalam penentuan kebijakan. Sedangkan kewajiban dokter keluarga menyangkut berbagai aspek sehingga dari hal tersebut hak dari dokter keluarga untuk mendapatkan perlindungan dan kepentingannya tidak terlindungi secara hukum.

Hubungan antara dokter keluarga sebagai penyedia pelayanan kesehatan dalam hubungannya dengan pasien sudah sesuai dengan ketentuan perundangan yang berlaku. Sedangkan hubungan antara PT. Askes (Persero) dengan peserta askes sudah sesuai dengan ketentuan yang ada.

3. Faktor-faktor yang Mempengaruhi Pelaksanaan Pelayanan Kesehatan oleh Dokter Keluarga Terhadap Peserta Asuransi Kesehatan di Kabupaten Temanggung

\section{a. Faktor Yuridis}

Faktor yuridis yang mempengaruhi adalah bentuk kewenangan dokter keluarga yang tidak jelas, karena tidak ada peraturan perundang-undangan yang mengatur. Peraturan yang ada pada perjanjian kerja sama tidak melindungi dokter keluarga.

b. Faktor Administratif

Faktor administrasi yang mempengaruhi adalah tidak terdokumentasinya dokter keluarga serta pengawasan dan pembinaan yang tidak jelas.

c. Faktor Demografi

Pengaruh dari faktor demografi disebabkan karena persebaran yang tidak merata antara dokter keluarga dan peserta askes.

d. Faktor Sosial

Faktor sosial yang mempengaruhi adalah karena pengetahuan peserta askes yang kurang tentang dokter keluarga dan sosialisasi yang kurang dari PT askes tentang pelayanan dokter keluarga. Pemahaman dokter keluarga tentang konsep pelayanan kesehatan dokter keluarga masih kurang. Dokter keluarga tidak melaksanakan upaya kesehatan dengan optimal untuk meninggatkan derajat kesehatan akan tetapi lebih mengutamakan kapitasi yang dicapai.

Kedudukan dokter keluarga secara hukum tidak terlindungi. Penerapan dokter keluarga menurut PT. Askes yang dilakukan oleh dokter keluarga belum dilaksanakan dengan sesuai peraturan yang ada. Proses pelaksanaan dokter keluarga tidak sesuai antara praktik dengan ketentuan yang ditetapkan pemerintah dalam permenkes. Praktik dokter keluarga masih bersifat kuratif sehingga tidak upaya pelayanan kesehatan dalam rangka meningkatkan derajat kesehatan belum dilaksanakan optimal. Perjanjian kerjasama antara dokter keluarga dengan PT. Askes lebih menguntungkan PT. Askes dalam pelayanan kesehatan, tetapi dalam perlindungan hukum tidak melindungi dokter keluarga.

SARAN

Berdasarkan hasil penelitian peneliti mengusulkan adanya beberapa saran untuk perbaikan keberadaan dokter keluarga supaya terlindungi secara hukum baik dari segi pelaksana pelayanan kesehatan maupun penerima layanan kesehatan.

1. Disarankan kepada Pemerintah Pusat agar menerbitkan Peraturan Pemerintah tentang dokter keluarga untuk memberikan kepastian hukum, perlindungan hukum dan cara pelaksanaan dokter keluarga dan pasien yang mendapat pelayanan. Segera dibuatkan regulasi tentang dokter keluarga untuk melindungi keberadaan dokter keluarga. 
2. Disarankan kepada Dinas Kesehatan agar membuat peraturan tentang pedoman pelaksanaan dokter keluarga, pembinaan, pengawasan dan pendidikan khusus bagi dokter keluarga. Administrasi yang jelas adanya dokter keluarga.

3. Disarankan kepada Dokter Keluarga agar membentuk kolegium Dokter Keluarga sebagai wadah yang melindungi anggota dokter keluarga dari praktik kedokteran yang dilakukan oleh dokter keluarga. Meningkatkan pengetahuan tentang pelayanan dokter keluarga serta meningkatkan pengetahuan tentang hak dan kewajiban yang berhubungan dengan perlidungan hukum dalam melaksanakan tugas dan wewenangnya.

4. Disarankan kepada PT. Askes agar lebih terbuka dalam pelaksanaan hubungan kerjasama dengan dokter keluarga. Lebih mensosialisasikan keberadaan dokter keluarga dan tidak ada pembatasan pelayanan dokter keluarga karena akan membatasi kewenangan yang sudah ada. Sosialisai pelayanan kesehatan yang dapat diterima oleh peserta askes dalam praktik dokter keluarga.

PT. Askes dalam mengadakan perjanjian kerjasama dengan dokter keluarga lebih mengutamakan asas kepastian hukum, perlindungan dan manfaat bagi kedua belah pihak. Hak dan kewajiban dokter keluarga lebih diperjelas dan seimbang antara keduanya. Menerapkan pelaksanaan dokter keluarga sesuai dengan peraturan yang sudah ada, sehingga tujuan meningkatkan derajat kesehatan dapat dilaksanakan.

\section{DAFTAR PUSTAKA}

BUKU

Abu Ahmadi, Psikologi Sosial, Bina Ilmu: Surabaya ,1982.

Abdulkadir Muhammad, Hukum dan Penelitian Hukum, Citra Aditya Bakti: Bandung, 2004.

Achmad Ali, Menguak Tabir Hukum, Ghalia Indonesia: Bogor, 2011.

Adolf Heuken,dkk, Ensiklopedia Etika Medis, Yayasan Cipta Loka Caraka: Jakarta,1979.

Agnes Widanti, Petunjuk penulisan usulan penelitian\&thesis, Universitas Soegijapranata: Semarang, 2009.

Ahmad Baequny,Tesis Analisis Tingkat Kepuasan Peserta Askes Sosial PT ASKES terhadap Pelayanan Dokter Keluarga di Kota Pekalongan tahun 2008, Fakultas IImu Kesehatan Masyarakat Universitas Diponegoro: Semarang, 2008.

Ali Gufron Mukti, Sistem Jaminan Kesehatan Konsep Desentralisasi Terintegrasi, KHM: Yogyakarta, 2008.

Alexandra Indriyani Dewi, Etika dan HukumKesehatan, Pustaka Book Publiser: Yogyakarta, 2008)

Amiruddin \& Zainal Asikin, Pengantar Metode Penelitian Hukum, Raja Grafindo Persada: Jakarta, 2003.

A.A. Gde Muninjaya, Manajemen Kesehatan, EGC: Jakarta, 2004.

Anonim, Sistem Kesehatan Nasional Tahun 2009.

Anonim, Panduan Lengkap Perundangan Asuransi, Pustaka Yustisia: Yogyakarta, 2010.

Arsita Eka Prasetyawati, Kedokteran Keluarga, Rineka Cipta: Jakarta, 2010.

Azrul Azwar, Dokter Keluarga, Direktorat Jenderal Bina Kesehatan Masyarakat DepKes RI: Jakarta, 2002.

, Refomasi Pelayanan Kesehatan, DEP KES.RI. DITJEN BINA KESMAS: Jakarta, 2004. 
Bahder Johan Nasution, Hukum Kesehatan Pertanggungjawaban Dokter, Rineka Cipta: Jakarta, 2005.

Bambang Sunggono, Metodologi Penelitian Hukum, PT Raja Grafindo Persada: Jakarta, 1998.

Bambang Waluyo, Penelitian Hukum dalam Praktek, Sinar Grafika: Jakarta, 1991.

Burhan Ashshofa, Metode Penelitian Hukum, Rineka Cipta: Jakarta, 2007.

Dedi Alamsyah, Manajemen Pelayanan Kesehatan, Nuha Medika: Yogyakarta, 2011.

Eny Rokhisah ,Tesis Analisis faktor-faktor yang berhubungan dengan niat Pegawai Negeri Sipil (PNS) terhadap Pelayanan Dokter Keluarga di Dinas P dan K Provinsi Jawa Tengah Tahun 2006 Fakultas Ilmu Kesehatan Masyarakat universitas Diponegoro: Semarang, 2006.

Fusia Meidiawaty, Upaya Preventif Dalam Pemeliharaan Kesehatan Anak dan Perlindungan Hukum Bagi Anak (tidak dipublikasikan) Tesis Magister Hukum Kesehatan Universitas Katolik Soegijapranata: Semarang, 2008.

H. Hendrojono Soewono, Perlindungan Hak-Hak Pasien dalam Transaksi Terapeutik, Srikandi: Surabaya, 2006.

Hilman Hadikusuma, Metode Pembuatan Kertas Kerja atau Skripsi Ilmu Hukum, Mandar Maju: Bandung, 1995).

Hasbullah Thabrany, Asuransi Kesehatan, Sinar Grafika: Jakarta, 2001.

Horton, Paul B,dan Chester L.hunt, Sosiologi (Alih Bahasa: Aminuddin Ram, Tita Sobari). Penerbit Erlangga: Jakarta,1993.

Info Askes, Buletin Bulanan PT. Askes (Persero) Edisi, Juni 2010

Junaedi Ganie,Hukum Asuransi Indonesia, Sinar Grafika: Jakarta, 2011.

Junita Eko Setiyowati,Perlidungan Hukum Peserta Bagi Hasil Di Suatu Perusahaan, Tesis Magister Ilmu Hukum Program Pascasarjana, UNPAR: Bandung, 2003.

Jurnal Kesehatan, Magister Kebijakan dan Manjemen Pelayanan Kesehatan, UGM: Yogyakarta, Juli 2008.

Jurnal Manajemen Pelayanan Kesehatan, vol11, no.2 Juni 2008

Majalah Kedokeran Indonesia, Volume: 58, Nomor: 2, Pebruari 2008

Ronny Hanitijo Soemitro, Metodologi Penelitian Hukum dan Jurimetri Ghalia Indonesia: Jakarta, 1988.

Samsi Jacobalis, Pengantar Tentang Perkembangan Ilmu Kedokteran, Etika Medis, dan Bioetika, Sagung Seto: Jakarta, 2005.

Sedarmayanti \& Syarifudin Hidayat, Metodologi Penelitian, Mandar Maju: Bandung, 2002.

Soekidjo Notoatmodjo, Metodologi Penelitian Kesehatan, Rineka Cipta: Jakarta, 2005.

, Etika\&Hukum Kesehatan, Rineka Cipta: Jakarta, 2010.

Soerjono Soekanto \& Mamudji, Penelitian Hukum Normatif (Suatu Tinjauan Singkat), Rajawali Pres: Jakarta, 2001.

Soerjono Soekanto, Aspek Hukum Kesehatan (Suatu Kumpulan Catatan), IND-HILL-CO: Jakarta, 1989.

,Pengantar penelitian Hukum, UI-Pres: Jakarta, 2010. 
Sofwan Dahlan, Hukum Kesehatan (Rambu-Rambu Bagi Profesi Dokter), Badan Penerbit Universitas Diponegoro: Semarang, 2005.

Strauss,A, Dasar-dasar Penelitian Kualitatif, Pustaka Pelajar: Yogyakarta, 2003.

Sulastomo, Manajemen Kesehatan, Gramedia Pustaka Utama: Jakarta, 2007.

, Sistem Jaminan Sosial Nasional (Sebuah Introduksi),: Rajawali Pers: Jakarta, 2008.

Titik Triwulan, Perlindungan Hukum bagi Pasien, Prestasi Pustaka: Jakarta, 2010.

Tjahjono Koentjoro, Regulasi Kesehatan di Indonesia, Andi: Yogyakarta, 2011.

Veronica Komalawati, Peranan Informed Consent dalam Transaksi Terapeutik, Cipta Aditya Bakti: Bandung, 2002.

Wiku Adisasmita, Sistem Kesehatan, PT Raja Grafindo Perkasa: Jakarta, 2007.

Wila Chandrawila Supriyadi, Hukum Kedokteran, Mandar Maju: Bandung, 2001.

Wiliam Chang, Bioetika Sebuah Pengantar, Kanisius: Yogyakarta, 2009.

Zainudin Ali, Metode Penelitian Hukum, Sinar Grafika: Jakarta, 2010.

Zunilda S Bustami, dkk, Hubungan kerja dokter keluarga, Bidan, dan perawat dalam pelayanan KB, Ikatan Dokter Indonesia: Jakarta, 1995.

PERATURAN PERUNDANG-UNDANGAN

Undang-Undang Dasar 1945

Undang-undang Nomor 40 tahun 2004 Tentang Sistem Jaminan Sosial Nasional

Undang-Undang Rl, Nomor 23 Tahun 2004 Tentang Penghapusan Kekerasan Dalam Rumah Tangga

Undang-undang Nomor 29 tahun 2004 tentang Praktek Kedokteran

Undang-Undang Nomor 17 tahun 2007, tentang Rencana Pembangunan Jangka Panjang Nasional (RPJPN)

Undang-undang Nomor 36 tahun 2009 tentang Kesehatan

Peraturan Pemerintah Nomor 6 tahun 1992 tentang Pengalihan bentuk Perusahaan Umum Husada Bhakti menjadi Perseroan (Persero).Perusahaan Umum Husada Bhakti menjadi Perseroan (Persero).

Peraturan Pemerintah RI, Nomor 2 Tahun 2002 Tentang Tatacara Perlindungan Korban dan Saksi Dalam Pelanggaran Hak Asasi Manusia Yang Berat

Peraturan Menteri Kesehatan RI Nomor 416 /Menkes/ Per/ II/2011 Tentang Tarif Pelayanan Kesehatan Bagi Peserta PT Askes (Persero).

Permenkes Nomor 2052 tahun 2011 tentang Izin Praktik dan Pelaksanaan Praktik Kedokteran

Keputusan Menteri Kesehatan Nomor 56/ Menkes/SK/1/1996 tentang Pengembangan dokter keluarga 


\section{INTERNET}

Ayu Witriasih,Praktek Dokter Keluarga,http:www.cybertokoh.com 18 Juni 2011

Rahayu, 2009, Pengangkutan Orang, etd.eprints.ums.ac.id.

http://hukumpedia.com/index.php?title=Akibat_hukum 23-2-2012

http://www.ppjk.depkes.go.id Powered by Joomla! Generated: 15 juni 2011

http://dokternews.wordpress.com/2011/05/20/72-306-pns-dilayani-dokter-keluarga/20 Mei 2011

http://m.suaramerdeka.com, 18 Maret 2011

http://www.kebijakankesehatan.co.ccc/2009/09/pengertian-kebijakan.html, 23 Juni 2011

http://deeshampoqu.wordpress.com/2010/02/11/dr-sugito-wonodirekso-ketua-perhimpunandokter-keluarga-indonesia-tercapainya-pelayanan-berkesinambungan-dengan-dokterkeluarga/ 9-12-2011

http://kylyaprayudha.blogspot.com/2011/03/pengertian-objek-hukum-objek-hukum.html 19-2-2012 http://arisandi.com/pengertian-peran-part-2-pelengkap/ 31-12-2011

http://www.prasko.com/2011/02/pengertian-perlindungan-hukum.html 23-2-2012 